\title{
DETERMINANTS OF WOMEN ENTREPRENEURSHIP SUCCESS IN ZIMBABWE. A CASE STUDY OF HARARE METROPOLITAN PROVINCE
}

\author{
Yeukayi Dzapasi ${ }^{1}$
}

\begin{abstract}
:
The role of women in economic development through participation in the informal sector has been widely reported in the extant literature. This study explores the determinants of women entrepreneurship success in the Harare Metropolitan Province, Zimbabwe. Self-completed questionnaires were used to collect data from four hundred (400) women entrepreneurs, as well as semi-structured interviews with key informants in the Harare Metropolitan Province. Data analysis used descriptive statistics. The study indicated the following determinants for success: leadership skills, managerial skills, education and training, motivation for success, confidence, self-esteem, creativity and innovation. In turn, the key factors inhibiting the success of women entrepreneurship included, lack of access to finance, poor regulatory environment, uncertain economic environment, societal stereotypes and poor family support. The study conclusions highlight the need for women entrepreneurs to cultivate leadership skills, improve business education skills and training, adopt innovative thinking and to craft creative strategies. The main recommendations emphasise the need for government support in mobilizing financial resources, simplifying licensing requirements, and reducing businessrelated taxes for women entrepreneurs.
\end{abstract}

Keywords: Entrepreneurship, Women entrepreneurship, Entrepreneurial development, Informal sector

\section{Introduction}

Participation of women in economic activities unlocks innate productivity that is instrumental to national income (Hassan and Yusof, 2015). Moges (2014) defines entrepreneurship as the ability to identify business opportunities, plan for exploitation, and sourcing the necessary resources to ensure the commencement and sustenance of the business. Entrepreneurship affords women the ability to improve income, as well as their standards of living while at the same time contributing meaningfully to the society and community they live in (Vossenberg, 2013). Women entrepreneurship is now a global phenomenon (Brush and Jennings 2013). In China women control 25\% of the businesses of which 60\% have been established over the last decade (Huang and Pen, 2012). The movement of the Chinese economy into an open market system, as well as extensive government support for women businesses

$\overline{{ }^{1} \text { Harare Institute of Technology; ydzapasi@gmail.com; ydzapasi@hit.ac.zw }}$ 
have been major factors leading to increased women entrepreneurship (Li and Zhang 2009). China has the potential to witness more success in women entrepreneurship if they overcome challenges of negative societal perceptions, take female entrepreneurs seriously, and address the balance of demands between business and family (Berg and Englund, 2015).

Women entrepreneurship has been on the rise in South Africa where almost half of the businesses are controlled by women (Kabeer, 2012). Factors cited for enhanced women empowerment in the country, include government supportive legislation, women education and confidence (Monyau and Bandara, 2015). However, the South African Women's Entrepreneur's Network report (SAWEN, 2015) cited poor access to capital, inadequate education and training and discrimination, as society still regards women's roles to be limited to household chores.

The study investigates the determinants of women entrepreneurship success in the Harare Metropolitan Province, Zimbabwe. The primary research objectives are to explore a) factors leading to women entrepreneurship success, and b) challenges impeding women entrepreneurship in Zimbabwe.

\section{Women Entrepreneurs in Zimbabwe}

Most women-run businesses in Zimbabwe are unregistered. Women entrepreneurs are confined to informal businesses and largely fail to penetrate business-oriented social networks which could enhance their prospects of getting higher-valued business deals (Brooks et al., 2014; Chipika, 2011). Most women entrepreneurs in Zimbabwe fail to establish formal businesses, due to challenges in accessing finance and limited access to profitable and high growth markets (Nani, 2011; Dzapasi and Machingambi, 2014). The Zimbabwe National Statistics Agency (ZIMSTAT) Labour Survey Report (2014) stated that $12.5 \%$ of women businesses are involved in non-farming and vending businesses, while $60 \%$ of the vendors in the agricultural sector are women who constitute $56.4 \%$ of the participants in the agriculture sector (see Table 1 below).

Table 1: Registered businesses

\begin{tabular}{|l|l|l|l|}
\hline Number of employees & Male owner & Female owner & Joint owner \\
\hline $\mathbf{0 - 4}$ & 18,464 & 5,298 & 3,603 \\
\hline $\mathbf{4 - 9}$ & 1,368 & 333 & 715 \\
\hline $\mathbf{1 0 - 1 9}$ & 726 & 97 & 345 \\
\hline $\mathbf{2 0 - 2 9}$ & 270 & 28 & 98 \\
\hline $\mathbf{3 0 - 4 9}$ & 208 & 17 & 77 \\
\hline $\mathbf{5 0 - 9 9}$ & 185 & 8 & 60 \\
\hline $\mathbf{1 0 0}$ and Above & 118 & $\mathbf{5}$ & $\mathbf{4 3}$ \\
\hline
\end{tabular}

Source: Zimstat (2015:485)

Table 1.1 indicates that women entrepreneurs had fewer registered businesses compared to their male counterparts. Against this background, this study sought to understand the key drivers of success in women entrepreneurship in Zimbabwe.

\section{Literature review \\ Perspectives on Entrepreneurship}

Several scholars have proposed different theories and frameworks in an attempt to explain and account for the success in women entrepreneurship. This section briefly considers the resource-based theory and the innovation theory. The resource-based theory underscores the need for resources and capabilities that enables entrepreneurs to formulate and implement viable business strategies (Kozlenkova, et al., 2014). Davcik et al. (2015) state that resources can be tangible or intangible, and include human capital, financial capital and social capital, respectively. Balashova and Gromova (2018) argue that the knowledge gained from education and experience, represents 
a resource that is distributed heterogeneously among individuals. This knowledge fosters an understanding of opportunities as they emerge in the market. In turn, Della Corte (2013) points out the significance of human capital towards the effective use of organizational resources for achieving maximum profitability and growth. An organization requires financial resources to purchase assets for use in the business, as well as financing expenses incurred in the day-to-day running of the business (Balashovaand Gromova, 2018). Day and Jean-Denis (2016) emphasize the social component and suggest that an individual may have the ability to identify the existence of an entrepreneurial opportunity in the community, but might lack relevant planning to convert the opportunity and become entrepreneurial.

Resources should be converted into capabilities for them to afford competitive advantage to the entrepreneur (Della Corte 2013). Capabilities enhance the ability to adapt, integrate and reconfigure resources, in order to maintain competitive advantage in a changing environment (Teece 2013), and they enhance the firm's ability to utilize resources effectively (Barney 2001). Capabilities are observable in the daily operations of the organization, and they are not documented, making it difficult for competitors to copy (Hall 1992) (Barney 2001). A firm's competitive advantage derives from its ability to create resources that are valuable, rare, inimitable and organized (referred to as the VRIO framework) (Kozlenkova, et al. 2014). Rare resources are unique to specific businesses within an industry, while inimitable resources are those that are difficult to duplicate or substitute (Bresser and Powalla, 2012). The VRIO framework gives rise to distinctive capabilities, which cannot be easily imitated by competitors, thus engendering distinctive capabilities from combinations of resources and capabilities, which create value through cost and differentiation advantage (Hua-Ling, Ya-Jung and Kiang 2012). A strategy is required for maximum exploitation of the firm's unique characteristics (Grant 1991). A strategic capability emerging from the resources and competencies enables an organization to prosper (Johnson et al 2008).

Notwithstanding these propositions, the resource-based theory has been criticized for a number of reasons, which include lacking substantiated managerial implications (Priem and Butler 2001), and identifying the VRIN resources without informing how this could be done (Connor 2002; Miller 2003). The theory invokes the illusion of total control, excluding property rights issues, thereby exaggerating the extent to which managers can control resources or predict their future value (Mcguineness and Morgan 2000), too indeterminate for useful application (Locket et al (2009), and devoid of acceptable law-like generalizations (Preim and Butler 2001). The inclusive definition of resources is problematic (Eisenhardt and Martin 2000; Teece et al 1997, Winter 2003), and the concept of values fails to draw some distinction between customer perception values and total monetary value and exchange (Bowman and Ambrosini 2000). Notwithstanding these divergent views, this study takes on board the emphasis from the RBT on the efficacy of resources that are critical for successful business operations and profitability. The next section reviews the innovation theory (Schumpeter, 1949) and related concepts.

Schumpeter (1947) defined innovation as the doing of new things through combining factors of production. Innovation theory postulates that entrepreneurship is the catalyst that disrupts the stationary circular flow of the economy, thereby initiating and sustaining the development process (Schumpeter, 1949). The Organization for Economic Cooperation and Development [OECD] (2015) argues that the concept of innovation and its corollary development, embraces five functions, namely the introduction of new products, new quality, new markets, new methods and new supply chains. Thus, innovation leads to the creation of new products, processes and services that brings value to the market. Bello and Adeoye (2018) reiterate that innovation is about conceiving new ideas and then implementing them successfully into the market so that they create value. Successful entrepreneurship is based on key competencies of creativity and innovation (Asenge and Agwa 2018). Innovation enables the business to focus on new challenges, as well as responding quickly and appropriately to changes in the marketplace (Ottih, 2014). Tidd and Bessant (2013) view innovation as an essential instrument used by entrepreneurs to exploit opportunities and bring about change.

Related theories on innovation include open innovation (Chesbrough 2003), innovation networks (Cornway and Stewart 2009) and absorptive capacity (Cohen and Levinthal, 1990). The open innovation propounded by Chesborough (2003), acknowledges the ubiquitous availability of knowledge and innovation outside the closed research laboratory environments, and the mobility and availability of highly educated people over the years. Cornway and Steward (2009) highlight the development on innovation networks from quite a number of ideas, which may or may not be embodied within the new products and services. They emphasize the importance of 
taking cognisance of individuals who introduce new ideas to the organization, integrating the messages, and valuing the contribution of people's creative contributions. In turn, absorptive capacity refers to the ability of a firm to "recognize the value of new external information, assimilate it and apply it to commercial ends" (Cohen and Levinthal 1990). The next section reviews empirical evidence on the factors influencing women entrepreneurship, drawing on the propositions and concepts reviewed in preceding sections.

\section{Key success factors}

Women entrepreneurship requires confidence, leadership, and managerial skills to navigate the business arena (Zhouqiaoqin et al 2013). Hawkins (2012) states that managerial efficiency is critical for women entrepreneurship success. A study by Cvetkovic (2015) in Serbia identified the following key success factors for women entrepreneurship: training and education, support from partner and family, inspiration of role models, and background of family business. Zhouqiaoqin et al. (2013) reported the determinants of women entrepreneurship in China in terms of human capital, women characteristics and motivation. A study by Neupane (2018) in the US emphasized mentorship, financial skills and managerial efficiency. This section reviews the role of confidence, leadership and education and training, managerial skills, motivation for success, background of family business, and creativity and innovation on women entrepreneurship.

\section{Confidence}

Confident women have the courage to fight for positions of power and control in the private as well as the public sphere (Mendryk and Dylon, 2014). Women in developing countries are groomed under unjust cultures and beliefs, and they suffer from the overbearing influence of male-dominated societies (Fatimah et al., 2014). Ewoh (2014) reported that Nigerian women were denied access to property and land ownership. A study by Mazonde (2016) on culture and self-identity among women entrepreneurs in Zimbabwe, highlighted the importance of overcoming stereotypes and the need for women to reinvent themselves in order to succeed as entrepreneurs in a developing country context.

\section{Leadership}

Kemkar and Sharma (2016) define leadership as power to influence. Neupane (2018) points out that leadership skills help build the cognitive ability of women to enable them to better master their desires and goal attainment. They propose that women entrepreneurs should develop leadership skills, problem-solving and decision-making skills.

\section{Education and Training}

Education improves the managerial skills of women entrepreneurs (Kolstad and Wiig (2013). Ewoh (2014) states that educated entrepreneurs are more calculative in risk-taking and opportunity-seeking and they have better prospects of success in exploring new business opportunities. Good education is one of the demographic factors that enhances the success of women entrepreneurs (Kimosop et al., 2016). Education enhances access to credit, as banks are assured that the borrower has the capacity to manage and repay the loan effectively (LeBlanc, 2013). Neupane (2018) highlights the significance of mentorship towards enhancing financial skills and managerial efficiency of women entrepreneurs and higher business growth in the United States of America. Nehad (2016) reports that entrepreneurship training, funding and family support were key to the success of women businesses in Afghanistan. Hassan (2013) reports that government funding and government education programmes were key to the success of women businesses in Kenya.

\section{Managerial skills}

Managerial skills are important for adapting and coping within changing business environments (Mas-Tur et al., 2015). Lack of access to managerial training is one of the major reasons for the underperformance of women businesses in developing countries (Chinonye et al., 2015). Mari et al. (2016) highlight that managerial skills are a critical success factor for women entrepreneurship.

\section{Motivation for success}

Motivation for success drives an individual's need for achievement (Karic, 2014). A motivated person exerts more effort in pursuing success (Przepiorka, 2017). Hui (2016) states that motivation for success is a key characteristic 
for women who flourish in business. Erogul and Quagrainie (2017) who investigated motivation, networking and business growth of women businesses in Ghana, noted the significance of motivation among successful women entrepreneurs.

\section{Background of family business}

Pérez-Pérez \& Avilés-Hernández (2016) state that family business background inspires women entrepreneurs and enhances their chances of success in business. Family business background acquaints the women entrepreneur on how businesses are run, which increases the probability of success in women entrepreneurship (Almobaireek and Manolova, 2013). Cvetkovic (2015) reports the significance of family support, the impact of role models, and family business background in Serbia. While the study by Zhouqiaoqin et al. (2013) in China report that the background of family business was not among the key factors determining the chances of success in women entrepreneurship.

\section{Creativity and innovation}

Creativity refers to the ability to come up with new ideas to solve problems (Bello and Adeoye, 2018). While innovation encompasses the introduction of new ideas, as well as the ability to successfully implement them in the market to add value (Tidd and Bessant, 2013). Highly creative and innovative women can come up with and put in place measures that curtail challenges and create sustainable competitive advantage (Asenge and Agwa 2018). Ottih (2014) highlights that innovation improves growth and profitability, as the firm explores new ways of enhancing organizational effectiveness.

\section{Barriers to entry}

Abdellatif et al, (2017) state that some societal cultures look down on women, thereby denying them the opportunities to venture into business. Metinleri (2018) reports that poor family support excludes women from power and respect, compared to males in Bahrain. Some cultural societal stereotypes depict women as too dominant and aggressive (Vossenberg, 2013). Metinleri (2018) cites lack of government support and legislation as barriers against women venturing into business, as well as accessing finance from banks. Chinonye et al. (2015) point out the lack of government support to access financial resources and educational support as inhibiting factors to women entrepreneurship. Nsengimana (2017) states that exorbitant taxes discourage women businesses from exiting the informal sector and venturing into larger and sustainable businesses. In Zimbabwe, most women businesses are unregistered and $12.5 \%$ of women businesses are involved in non-farming and non-vending activities (Finscope Report 2012). Dzapasi and Machingambi (2014) report poor access to financial resources, due to lack of collateral, thus denying women entrepreneurs access to loans from commercial banks. Ewoh (2014) cites lack of managerial efficiency which leads to poor decision-making, poor staff motivation, lack of strategic planning, and poor oversight, which result in reduced performance by women entrepreneurs. The lack of financial resources inhibits women from hiring skilled labour (Bonnie, 2016). The primary research objectives in this study are to explore a) the factors leading to women entrepreneurship success, and b) challenges impeding women entrepreneurship in Zimbabwe.

\section{Methodology}

The study adopted a qualitative descriptive research approach to elicit respondents' accounts of meaning and experiences, or perceptions (De Vos, 2002; Wube, 2010). Data collection used a self-administered questionnaire comprising closed and open-ended items. Questionnaires are widely used in collecting survey information (Saunders et al., 2009; Bryman and Bell, 2007; Erikson and Kovalainen, 2008). The case study design located the phenomenon within the context in which it was studied (Yin 2013). This enabled the collection of data within their natural settings, whilst attempting to make sense of, and interpret the meanings participants bring to them (Denzin and Lincoln, 2005). The research approach enabled gaining rich understanding of the research context and the processes that was enacted (Morris and Wood, 1991). This enabled the generation of empirical data and information important for understanding the research context (Eisenhardt et al, 2007). The population of the study comprised registered women SMEs that had been in operation for at least 5 years in Harare Metropolitan Province, Zimbabwe.

Purposive sampling used snowballing to obtain information on women entrepreneurs in Zimbabwe from the Women Alliance of Business Associations in Zimbabwe (WABAZ). Miller (2015) highlights the importance of characteristics representative of the theme of the study, so that results can be generalized among the respondents. The sample 
size was calculated using Raosoft sample size calculator, based on a population of 1920 , with a $5 \%$ margin of error, confidence interval of $95 \%$ and a 50\% response distribution. This yielded a sample size of 321 women businesses in Harare Metropolitan Province. Participation in the study was voluntary, and to ensure anonymity participants were asked not to write their names on the questionnaire. The questionnaire was pilot-tested to check the relevance and usability of the items. All the questions were found to be clear to participants and they were assured that their responses would be kept confidential and used only for this study.

Descriptive statistics were used to analyse the data. ANOVA was used to test the significance of the research findings. Frequencies and percentages were used to present the data. The data are presented in Tables 2-4 below.

\section{Results}

Table 2: Demographic characteristics of women entrepreneurs

\begin{tabular}{|c|c|c|c|c|c|c|c|}
\hline $\begin{array}{l}\text { Demographic } \\
\text { Characteristic }\end{array}$ & Category & Frequency & $\%$ & $\begin{array}{l}\text { Demographic } \\
\text { Characteristic }\end{array}$ & Category & Frequency & $\%$ \\
\hline \multirow[t]{4}{*}{ Age } & 20-30 years & 66 & 21.2 & Marital Status & $\begin{array}{l}\text { Single never } \\
\text { married }\end{array}$ & 14 & 11.30 \\
\hline & $31-40$ years & 111 & 35.7 & & Married & 47 & 37.90 \\
\hline & $41-50$ years & 88 & 28.2 & & Divorced & 34 & 28.00 \\
\hline & $\begin{array}{l}50 \text { and more } \\
\text { years }\end{array}$ & 46 & 14.8 & & Widowed & 28 & 22.80 \\
\hline \multirow[t]{5}{*}{ Education level } & O/A level & 17 & 13.8 & Age of business & $5-7$ years & 19 & 15.40 \\
\hline & Certificate & 19 & 15.1 & & $7-10$ years & 27 & 22.00 \\
\hline & Diploma & 24 & 19.6 & & $10-15$ years & 33 & 26.80 \\
\hline & Degree & 38 & 30.9 & & $15-20$ years & 22 & 17.90 \\
\hline & $\begin{array}{l}\text { Postgraduate } \\
\text { degree }\end{array}$ & 25 & 20.6 & & Above 20 years & 22 & 17.90 \\
\hline
\end{tabular}

Source: Questionnaire Response

Table 2 above shows that the age distribution constituted 21.2\% (age 20-30 years), 35.7\% (age 31- 40 years), $28.2 \%$ (age $41-50$ years) and $14.8 \%$ for the age group above 50 years. Most of the respondents were between 31 and 40 years old. Education levels showed that $30.9 \%$ held first degrees, $20.6 \%$ had postgraduate degrees, while $19.6 \%$ had diplomas. The time-in-business variable indicates that $15.4 \%$ had been doing business for 5-7 years, $21.9 \%$ for $7-10$ years, $27 \%$ for $10-15$ years, $18 \%$ for $15-20$ years and $17.7 \%$ for at least 20 years. Most of the businesses had been in operation for an average of 10 years, which provide some basis for assessing factors pertinent in this study.

\section{Determinants of successful women entrepreneurship in Zimbabwe}

Respondents were asked to indicate their views on a 5-point Likert Scale where 1 is strongly disagree to 5 is strongly agree. Mean scores below 2.5 indicate the respondents did not agree, between 2.5 and 3.5 that they agreed, and above 3.5 that they strongly agreed. These are shown in Table 3. 
Table 3: Determinants of success for women entrepreneurs

\begin{tabular}{|l|l|l|l|}
\hline Determinants of women success & Mean & St. deviation & P-values \\
\hline Leadership skills & 3.60 & 1.248 & 0.16 \\
\hline Managerial skills & 4.73 & 0.664 & 0.44 \\
\hline Motivation for success & 2.82 & 1.232 & 0.40 \\
\hline Confidence and self esteem & 2.74 & 1.501 & 0.17 \\
\hline Family background in business & 2.08 & 2.680 & 0.23 \\
\hline Level of education & 2.57 & 1.622 & 0.19 \\
\hline Creativity and Innovation & 3.54 & 0.914 & 0.07 \\
\hline
\end{tabular}

Source: Questionnaire Response

Leadership skills had a mean score of 3.60, thereby indicating that most respondents recognize the significance of these skills in successful entrepreneurship endeavors. This supports observations by Kemkar and Sharma (2016). Managerial skills indicated a mean score of 4.73 , indicating that most of the respondents strongly agreed that these skills are a key success factor in women entrepreneurship. These findings concur with Brush et al. (2009), who reported the importance of training and education towards enhancing managerial skills for women entrepreneurs.

Motivation for success had a mean score of 2.82. This indicated that the respondents agreed that it was a key success factor for women entrepreneurship. This supports Erogul and Quagrainie (2017) who observed the relationship between motivation, networking and business growth in women businesses in Ghana. Confidence and self-esteem were cited as key to successful women entrepreneurship and supports Zhang (2012). Family background in business had a mean score of 2.08, thus was not confirmed as a key to success in women entrepreneurship in Zimbabwe. This echoes observations by Zhouqiaoqin et al. (2013) on the insignificance of family background in business on women entrepreneurship success in China. Notwithstanding, findings by Pérez-Pérez and Avilés-Hernández (2016) reported the significance of family business background as key to successful women entrepreneurship. Level of education had a mean score of 2.57, indicating that it was considered as a key determinant of successful women entrepreneurship and support observations by Kelly et al. (2013). Creativity and innovation scored 3.54, indicating that respondents recognized this as significant in women entrepreneurial success. The findings support observations by Ottih (2014) on the role of innovation in exploiting new ways for enhancing organizational effectiveness, thereby improving business growth and profitability.

\section{Barriers to entry impeding women entrepreneurship}

Table 4: Barriers and impeding women entrepreneurship in Zimbabwe

\begin{tabular}{|l|l|l|l|}
\hline Challenges for women entrepreneurship & Mean & St. deviation & P-values \\
\hline Inability to access financial resources & 4.02 & 0.911 & 0.10 \\
\hline Shortage of skilled labour & 2.13 & 0.893 & 0.13 \\
\hline Lack of education & 2.48 & 1.722 & 0.21 \\
\hline Poor family support & 2.72 & 1.061 & 0.44 \\
\hline Too high taxes & 2.81 & 1.899 & 0.79 \\
\hline Strict government regulation & 3.37 & 1.622 & 0.32 \\
\hline Constraints in the economy & 4.42 & 0.426 & 0.33 \\
\hline $\begin{array}{l}\text { Societal stereotypes of women entrepreneurs } \\
\text { being dominant and aggressive }\end{array}$ & 2.52 & 1.711 & 0.17 \\
\hline
\end{tabular}

Source: Questionnaire Response 
Table 4 above shows that Inability to access to financial resources had a mean score of 4.02, which indicates that respondents cited this as a barrier to women entrepreneurs. This supports Dzapasi and Machingambi (2014) on the challenges faced by women in accessing financial resources in Zimbabwe. Lack of skilled labour scored 2.13, and was thus not considered a barrier nor a challenge to women entrepreneurship. However, Bonnie (2016) highlights that insufficient financial resources prevent most women entrepreneurs from hiring skilled labour. Lack of education scored 2.48 and was not considered a barrier. This supports Nyoni (2017) who reported that 51\% of the women entrepreneurs had ordinary level qualifications and were generally conversant with business-related matters. Chinomona and Maziriri (2015) reported a lack of education as a barriers for women entrepreneurs in South Africa. Poor family support scored 2.72, indicating that respondents found this to be a barrier impeding women entrepreneurship in Zimbabwe. This supports findings by Metinleri (2018) in Bahrain. High taxes had a mean score of 2.81, indicating that this was a barrier for women entrepreneurs. This supports Nsengimana (2017) who cites the negative impact of high taxes on small business ventures. Strict government regulations had a 3.37 mean score, indicating the negative impact of the regulations on women entrepreneurship. Liquidity challenges had a mean score of 4.42, indicating that it was one of the major barriers and challenges faced by the women entrepreneurs. These findings support observations by Nyoni (2017) on major factors affecting the success of female food vendors in Harare. Societal stereotypes of women entrepreneurs had a mean score of 2.52, highlighting respondents' views that societal stereotypes impeded women entrepreneurial success. These findings support Abdellatif et al. (2017) and Vossenberg (2013), who reported the negative impact of societal cultures and societal stereotypes of women as a stumbling block to women entrepreneurship.

\section{Factors that enhance the rate of success for women entrepreneurs}

Table: 4. Policies and Legislation and impact on the success of women entrepreneurs

\begin{tabular}{|l|l|l|l|}
\hline $\begin{array}{l}\text { Policies and Instruments to } \\
\text { enhance women entrepreneurship success }\end{array}$ & Mean & St. deviation & P-values \\
\hline Facilitating lines of credit for women entrepreneurs & 4.63 & 0.322 & 0.33 \\
\hline Encouraging and facilitating women's social networks & 3.71 & 1.455 & 0.08 \\
\hline Enhancing women's entrepreneurial education and skills & 2.78 & 1.291 & 0.29 \\
\hline Encourage societal tolerance of women entrepreneurship & 2.67 & 1.763 & 0.41 \\
\hline Encourage strategic management and corporate governance & 3.41 & 1.711 & 0.18 \\
\hline Improve the friendliness of the macroeconomic environment & 3.65 & 0.840 & 0.46 \\
\hline Providing adequate regulatory support from government & 2.98 & 1.317 & 0.28 \\
\hline
\end{tabular}

Source: Questionnaire Response

The question was based on a Likert scale, ranging from 1 is not effective to 5 is very effective. Table 5 above shows rankings by respondents in terms of how they perceived the impact of policies and legislation on the success of women entrepreneurship in Zimbabwe.

Facilitating lines of credit for women entrepreneurs had a mean score of 4.63, showing that the respondents viewed this as significant for enhancing the success of women entrepreneurs. This supports Hassan (2013) who noted the need for governments to source cheaper credit lines to finance women entrepreneurship projects. Encouraging and facilitating women's social networks scored 3.71, indicating that most respondents regarded the factor to be effective in making women entrepreneurship successful. Kotler and Keller (2012) noted the significance of networking, marketing and organizational learning on the success of business organisations. Enhancing women's entrepreneurial education and skills had a score of 2.78 , indicating the significance of this towards improving women entrepreneurship. This supports observations by Vossenberg (2013) on the importance of prioritizing education and training in the development of strategic management skills among women entrepreneurs. The study findings on encouraging societal tolerance had a mean score of 2.67, and supports observations of Berg and Englund (2015) on the impact of negative societal cultural values on women entrepreneurship. 
Encouraging strategic management and corporate governance scored 3.41, thus highlighting the significance of this factor towards enhancing the success of women entrepreneurship. The study findings support Przepiorka (2017), who reported the significance of developing effective strategies in creating value for entrepreneurial ventures. Padachi et al. (2016) highlighted the need to ensure transparency and accountability in business management. Improving the friendliness of the macroeconomic environment scored 3.65. This supports observations by Nyoni (2017) on the significance of stable macroeconomic environments for business organisations to thrive and grow. Lastly, adequate regulatory support from government scored 2.98, underscoring observations by Nsengimana (2017) on importance for governments and local municipalities to simplify the registration processes and operating requirements for women entrepreneurs and businesses in general.

\section{Conclusions and Recommendations}

The study identified the following critical factors for the success of women entrepreneurship: leadership skills, managerial skills, education and training, motivation for success, confidence and self-esteem, and creativity and innovation. The major challenges impeding successful women entrepreneurship include lack of access to financial resources, poor family support, high taxes, strict government regulation, liquidity challenges and negative societal stereotypes.

The study's recommendations for women entrepreneurs is that they should develop leadership skills, sharpen managerial efficiency through education and training, and embrace creativity and innovations in their business operations. The study's recommendations for government, include implementing economic policies that promote stable macroeconomic environments that enable women entrepreneurs to operate, mobilize cheaper financial resources for women entrepreneurs, provide simpler registration procedures, reduce taxes as well as prohibitive legislative policies and regulations for women. Government and non-governmental organisations should, inter alia, capacitate women entrepreneurs by offering training programmes on business management, financial management for small businesses, strategy, marketing and corporate governance.

The study limitations included time and resources which confined the research to the Harare Metropolitan Province. Future research should focus on different parts of the country, using a range of research methods to enhance our indepth understanding of the determinant of success in women entrepreneurship within the context of a developing country.

\section{References}

Abdellatif, L. M., Ramadan, M and Elbakry, S. A. (2017) How Gender Biased Are Female-Headed Household Transfers in Egypt? In Economic Research Forum Working Papers (No. 1126).

Allen T (1977) Managing The Flow of Technology,Technology Transfer and The Dissemination of Technological Information within R\& D Organisations: Massacheusets:MIT Press

Almobaireek, N. W and Manolova, T. (2013) Entrepreneurial motivations among female university youth in Saudi Arabia, Journal of Business Economics and Management, Vol 14, Issue 1, pp 56-75.

Asenge, E.L and Agwa, T.R. (2018) Entrepreneurial Competencies and Entrepreneurial Mindset as Determinants of Small and Medium Scale Enterprises Performance in Nigeria, Global Journal of Management and Business Research, Volume 18, Issue 13, pp 25-34

Balashova, E.S and Gromova, E.A. (2016) Resource-based view as a perspective management model in Russian reality, Problemsand Perspectives in Management, Vol 14, Issue 2-2), pp 325-330

Barney,J.B (1991) Firms Resources and Sustained Competitive Advantage -A Journal of Management,17:99-120

Berg, S and Englund, M. (2015) Female Entrepreneurship in China- A Comparative Study between Male and Female Entrepreneurs, Thesis submitted in partial fulfillment of a Masters' Degree in Project Innovation and Industrial Management, University of Gothenburg.

Bello, O.B and Adeoye, A.O. (2018) Organizational learning, organizational innovation and organizational performance: Empirical evidence among selected manufacturing companies in Lagos metropolis, Nigeria, Journal of Economics and Management, Vol 33 Issue 3, pp 25-38 
Bowman C and Ambrosini V (2000, Value Creation versus Value Capture:Towards a coherent definition of value in Strategy, British Journal OF Management II 1-15

Bresser, R.F.K and Powalla, C. (2012) Practical implications of the Resource Based View: Assessing the predictive power of the VRIO Framework, Zeitshrift fur Betriebswirtschaft, Vol 82, Issue 4, pp 335-359.

Bromiley P and Papenhouse C (2003) Assumptions of Rationality and Equilibrium in Strategy Research: The Limits Of Trditional Economic Analysis,Strategic Organisation I:413-437

Brooks, A. W., Huang, L., Kearney, S. W. \& Murray, F. E. (2014) Investors prefer entrepreneurial ventures pitched by attractive men, Proceedings of the National Academy of Sciences, Vol 111, Issue 12, pp 4427-4431

Brush, C. G and Jennings E. J. (2013) Research on women entrepreneurs - challenges to (and from) the broader entrepreneurship literature, The Academy of Management Annals, Vol 7, Issue 1, pp 663-715.

Calantone R and Cooper R (1981) New Product Scenarios for Success: Journal of Marketing 45(48-60)

Chesborough H (2003) Open Innovation:The New Imperative for Creating and Profiting From Technology, Harvard Business School Press.

Cohen W M and Levinthal M D A (1990) Absorptive Capacity:A New Perspective on Learning and Innovation Adminstrative Science Quarterly 35(1) 128-152.

Chidoko, C. and Makuyana, G. (2012) The Contribution of the Informal Sector to Poverty Alleviation in Zimbabwe, Developing Country Studies, Vol 2, Issue 9, pp 41-44.

Chinonye, M.L., Iyiola, O.O., Akinbode, M.O., Obigbemi, I.A and Eke, O.P. (2015) Women Entrepreneurship in Nigeria: Policy Framework, Challenges and Remedies, Kasmera, Vol 43, Issue 2, pp 2-21.

Chipika, S. (2011) Economic Empowerment of Women: Agriculture Sector Study. Ministry of Women Affairs, Gender and Community Development, World Bank; Finance and Private Sector Development Unit

Cornway S (1977) Stratgic Personal Links in Successful Innovation:Link pins Bridges, Bridges and Liasons, Creaticity and Innovation Management 6(4) 226-233

Cvetkovic, M.Z. (2015) Women entrepreneurship in Serbia A qualitative study of the perceived enabling factors for the female entrepreneurship, Thesis submitted in partial fulfillment of a aster's degree in Environmental Economics and Management, Sweden: Swedish University of Agricultural Sciences.

Davcik, N.S., da Silva, R.V and Hair, J. (2015) Towards a unified theory of brand equity: Conceptualizations, taxonomy and avenues for future research, Journal of Product and Brand Management, Vol 24, Issue 1, pp 3-17.

Day, S.W and Jean-Denis, H. (2016) Resource Based View of Social Entrepreneurship: Putting the Pieces Together, Journal of Strategic Innovation and Sustainability Vol 11, Issue 2, pp 59-69.

Della Corte, V. (2013) Tourist firms and systems: The management, 2nd Ed, Milan: Egea.

Dzapasi, Y and Machingambi, J. (2014) Sources of Finance for Women Micro and Small Enterprises (MSEs) in Zimbabwe: A Study of Selected Women MSEs in Harare Town, IJMIE Volume 4, Issue 7 ISSN: 2249-0558.

Erogul, M. S and Quagrainie, F. A. (2017) Motivation, Networking and Business Growth: Perspectives of Ghanaian Female Entrepreneurs, Journal of Enterprising Culture, Vol 25, Issue 3, pp 297-316

Ewoh, E. (2014) Female entrepreneurship: A systematic literature review of the forces affecting the performane of African female entrepreneurs, Thesis submitted in partial fulfilment of a Master's degree, Jyvaskyla University.

Fatimah, H., Aznarahayu, R and Nasina, M. D. (2014) Rural women entrepreneurs in Malaysia: What drives their success? International Journal of Business and Management, Vol 9, Issue 4, pp 10-21.

Finscope (2012) Finscope MSMEs Report, Harare: Research Continental Fonkom, Finmark Trust

Gibbons M and John Ston R (1974). The Roles Of Science in Technological Innovation, Research Policy3(3)220-242

Hassan, I.B. (2013) Determinants of Growth for Women Owned and Operated Micro Enterprises: The Case of Garissa, Kenya, International Journal of Business and Commerce, Vol 2, Issue 7, pp 45-55 
Hassan, K. and Yusof, R. (2015) Women in Economic and Social Transformation Era: Issue and Challenges, India: UUM Press.

Hawkins, W.G. (2012) Exploring Success Factors of Female Entrepreneurs in The Texas Child Care Market, Thesis submitted in partial fulfillment of aDoctor of PhilosophyDegree, Prescott, Valley, Arizona: Northcentral University

Helfat C E and Peteraf MA (2003) The Dynamic Resources Based View: Capability Lifecycles, Strategic Management Journal 24(10)997-1010

Holt. D. (1992) Entrepreneurship: new venture creation, Englewood Cliffs, NJ, Prentice Hall.

Hua-Ling, L., Ya-Jung, T and Kiang, M. (2012) A fuzzy quantitative VRIO Framework for evaluating activities, Management Decision, Vol 50, Issue 8, pp 1396-1411.

Hui, M.K. (2016) Determinants of Entrepreneurship Success among Women Entrepreneurs in Kota Kalibalu, Sabah. Thesis submitted in partial fulfillment of Master of Business degree, Malaysia: Universiti Malaysia Sabah.

Kabeer, N. (2012) Women's economic empowerment and inclusive growth: labour markets and enterprise development, SIG WORKING PAPER 2012/1, School of Oriental and African Studies, UK

Karic, M. (2014) Motivation of Public Sector employees: The case of the Novi Grad Sarajevo Municipality, A Thesis submitted in Partial Fulfilment of a Master of Business Administration Degree, Serbia: Ljubljana University.

Kemkar, M and Sharma, J. (2016). Women Entrepreneurship - Factors leading to Success of Women Led Enterprises, Res. J. Management Sci., Volume 5, Issue (9), pp 46-50

Kimosop, J., Korir, M and White, M. (2016) The moderating effect of demographic characteristics on the relationship between strategic capabilities and firm performance in women-owned entrepreneurial ventures in Nairobi, Kenya, Canadian Journal of Administrative Sciences, Vol 33, pp 242-256.

Kolslad, I., \&Wiig, A. (2013) Human Capital, Social Capital and Entrepreneurial Success, Journal of International Development Vol 5, Issue 25, pp $626-627$.

Kozlenkova, I., Samaha, S and Palmatier, R. (2014) Resource-based theory in marketing, Journal of the Academy of Marketing Science, Vol 42, Issue 1, pp 1-21.

Langrish J, Gibbons M, Evans N and Jevans F (1972) Wealth Firm Knowledge: A study of Innovation and Industry, London:Macmillan

LeBlanc. (2013) The Effect of Education and Knowledge, Experience, Mentoring, And Risk on the Successful Entrepreneur: A Qualitative Study, Thesis submitted in partial fulfillment of a PHD degree, Minneapolis, USA: Capella University.

Leiblein P and Papenhouse C (2003). The Choice of Organizational Governance Form and Performance: Predictions from Transactions Cost, Resource Based and Real Options Theories. Journal of Management29:937-961

Mari, M., Poggesi, S and De Vita, L. (2016). Family embeddedness and business performance: Evidences from women-owned firms, Management Decision, Vol 54, Issue 2, pp 476-500.

Marlow, S and McAdam, M. (2013) Gender and entrepreneurship: advancing debate and challenging myths; exploring the mystery of the under-performing female entrepreneur, International Journal of Entrepreneurial Behavior \& Research, Vol 19, Issue 1, pp 114-124.

Mas-Tur, A., Pinazo, P., Tur-Porcar, A and Sánchez-Masferrer, M. (2015) What to avoid to succeed as an entrepreneur? Journal of Business Research, Vol 68, Issue 11, pp 2279-2284.

McGuiness and Morgan R E. (2000) Dynamic Capabilities and Complex Science: Management Rhetoric Versus Reality Strategic Change 9:209-220

Mendryk, I and Dylon, D. (2014). Factors of Professional Success for Self-Employed Women. In Human Capital without Borders: Knowledge and Learning for Quality of Life, Proceedings of the Management, Knowledge and Learning International Conference, Portoroz, Slovenia (pp. 933-938) 
Moges, B. (2014) The Relationship of Motivational and Success Factors with Entrepreneurial Success in Addis Ababa: The Case of Alliance of Ethiopian Women Entrepreneurship Program (AWEP) members, Thesis submitted in Partial Fulfillment of a Degree of Master's in Business Administration (MBA), Ethiopia: Addis Ababa University.

Monyau, M. M and Bandara, A. (2015) Zimbabwe 2015. [Online]. Available at: www.africaneconomicoutlook.org [Accessed 9 April 2017]

Metinleri, T. (2018) Women Entrepreneurs in the Gambia: Investigating the Challenges and Motivation of Women Entrepreneurs in the Gambia, Working Paper, WPS NO / 171/ 2018-05, Instabul: İstanbul TicaretÜniversitesi

Nani, G. V. (2011). Challenges faced by urban Zimbabwean women entrepreneurs, Thesis submitted in Partial Fulfillment of a doctoral degree, Free State: University of the Free State.

Nsengimana, S. (2017) Challenges to Women Entrepreneurship in Kigali, Rwanda, Thesis submitted in partial fulfilment of a Master of Technology: Business Administration in Entrepreneurshipdegree Cape Town: Cape Peninsula University of Technology

Niethammer, C. (2013) Women, Entrepreneurship and the Opportunity to Promote Business and Development. The 2013 Brookings Blum Roundtable Policy Briefs

Ndofirepi, T. M. (2016). Impact of technological creativity and entrepreneurship education on the entrepreneurship intention of students at particular tertiary institutions in South Africa and Zimbabwe. Thesis submitted in partial fulfillment of a doctoral degree, Free State: Central University of Technology

Neupane, S. (2018) Let me give you a hand: A Phenomenological study of Women Entrepreneurs, Financial Competency, and Mentorship, Thesis submitted in partial fulfillment of a Doctor of Philosophy in Family Sciences degree: Texas: Texas Woman's University

Nyoni, T. (2017) An empirical investigation of factors affecting the performance of women entrepreneurs in Harare: a case of food vendors, MPRA Paper No. 87523, Munich: Munich Personal RePEc Archive

Ottih, L.O. (2014). Entrepreneeurship: Personality, Process and Enterprise, Port Harcourt, Nigeria: Pearl Publishers.

Padachi,K., Urdhin, H.Rand Ramen, M.(2016) Assessing Corporate Governance Practices of Mauritian Companies, International Journal of Accounting and Financial Reporting, Vol 6, Issue 1, pp 38-71.

Penrose E T (1959) ,The Theory of The Growth of The Firm (1995ed),New York:John Wiley and Sons

Pérez, C.P., Hernández, M.A.\&Pérez,J.L. M.(2015)MotivosporlosqueseestudialngléscomosegundalenguaenEspaña. laexperiencia del aprendizajeenlasescuelasoficiales de idiomas (EOI)RevistaLugares de Educação, Vol 5, Issue 11, pp 183-210.

Preim R L and Butler J E (2001a), Is The Resource Based View a Useful Perspective for Strategic Management Research? Academy of Management Review, 26 22-40

Preim R L and Butler J E (2001b), Tautology in the Resource Based View and the Implications of Externally Determined Resource Value: Further Comments, Academy of Management Review, 26-57-66

Przepiorka, A. M. (2017) Psychological Determinants of Entrepreneurial Successand Life-Satisfaction, Current Psychology, Vol 36, pp 304-315

Rothwell R, Freeman C, Horsely A, Robertson A and Townsend J (1974) SAPPHO Updated-Project SAPPHO Phase II Research Policy 3(3) 258-291

Sabri, N. (2015) From Invisibility to Visibility: Female Entrepreneurship in Afghanistan, Thesis submitted in partial fulfillment of a Master of Arts in International Studies degree, Oregon: University of Oregon.

Schumpeter, J.A. (1949) Economic Theory and Entrepreneurial History, Change and the Entrepreneur, pp.63-84, repr. in R.V. Clemence (ed.) Essays of J. A. Schumpeter, Cambridge, Mass.: Addison-Wesley, pp.248-266

Sefa, S.R. (2014) The Impact of Market orientation and Innovation on SME performance: The case of Kosovo, A thesis submitted in partial fulfilment of master's degree from the faculty of Economics, Kosovo: University of Ljubljana. 
Sheheli V (2012) Improving livelihood of rural women through income generating activities in Bangladesh. octoral dissertation, Humboldt-Universitätzu Berlin, LandwirtschaftlichGärtnerischeFakultät.

Teece D. (2013) Dynamic Capabilities \& strategic management: Organizing for Innovation and Growth, Oxford, UK: Oxford University Press.

Tidd, J. \& Bessant, J. (2013) Managing Innovation - Integrating Technological, Market and Organizational Change, 5th Ed, West Sussex: John Wiley \& Sons Ltd.

Ushewokunze, T.E. (2012) An Investigation into the Egalitarian Assumptions of Aid Providers in Women Empowerment Projects and Lived Experiences of Women within Patriarchal Societies, A case of Zimbabwe. University of Gothenburg Vossenberg, S. (2013) Women Entrepreneurship Promotion in Developing Countries: What explains the gender gap in entrepreneurship and how to close it? Working Paper No. 2013/08

Zahra S A and George G (2002) "Absorptive Capacity, A review reconceptualisation and extension"Academy of Management Review 27(2) 185-203

Zahra S, van deVelde and Lranneta B (2007) "Knowledge Conversion Capability and the Performance of Corporate and University Spin offs" Industrial and Corporate Change (16)569-608

Zhang K.L (2012) Difference of Chinese entrepreneurs between man and women, pp 197-199

Zhouqiaogin, Xie, Y.Y., Zhang, L and Kumah, S. (2013) Factors that influence the success of women entrepreneur in China: a survey of women entrepreneurs in Beijing, Journal Of Humanities And Social Science, Vol 18, Issue 3, pp 83-91

ZIMSTAT (Zimbabwe National Statistics Agency). (2015b) 2014 Labour Force Survey, Harare: ZIMSTAT.

http://www.zimstat.co.zw/sites/default/files/img/publications/Labour/Labour_2014.pdf. (Accessed 4 March 2017). 